\title{
A NEW SPECIES OF PONTHIEVA (ORCHIDACEAE, SPIRANTHOIDEAE) FROM ECUADOR
}

\author{
Marta Kolanowska ${ }^{1} \&$ Dariusz L. SzlachetKo
}

\begin{abstract}
A new species of Ponthieva R. Br., Ponthieva jamesonii is described and illustrated based on Ecuadorian material. The taxonomic affinity of the new entity is briefly discussed.
\end{abstract}

Key words: Ponthieva, Neotropics, new species, Orchidaceae, taxonomy

Dariusz L. Szlachetko \& Marta Kolanowska, Department of Plant Taxonomy and Nature Conservation, University of Gdańsk, Wita Stwosza 59, 80-308 Gdańsk, Poland; e-mail: martakolanowska@wp.pl

\section{INTRODUCTION}

The Neotropical genus Ponthieva was proposed by Brown (1813) to separate Neottia glandulosa Sims distinguished by its rosulate, shortly petiolate leaves, glandular-hairy ovary and floral bracts, as well as by the clawed petals and lip, both connivent to the gynostemium. The generic name was given in honor of Henry de Ponthieu, a London merchant who was sending plant collections from the West Indies to Joseph Banks in the late $18^{\text {th }}$ century.

The specific content of initially monotypic Ponthieva quickly increased - over 90 species have been described since then. Many of them have been transferred to other genera or synonymized, however; currently ca 30 species are recognized within the genus (Salazar 2005; Dueńas Gómez \& Fernández Alonso 2009). Ponthieva may be defined by a series of morphological characters. Apart from the foregoing, they have thin leaves, membranaceous floral bracts, usually pubescent sepals, strongly asymmetric petals and a fleshy, relatively small lip. The gynostemium is short, lacking a column-foot. The wing-like staminodes are fused with the filament and with the stigma margins, forming a prominent dorsal clinandrium (Szlachetko \& Rutkowski 2000). The only taxon

\footnotetext{
1 Corresponding author
}

that remains an object of intense taxonomic discussion is the species described initially as Goodyera fertilis F. Lehm. \& Kraenzl. (Kränzlin 1899), which in a short time was transferred to Cranichis by Schlechter (1921). The distinctive characters of the species led to its separation on the generic level, as Exalaria by Garay and Romero-Gonzalez (1999), but recently the species was also suggested to be a representative of Ponthieva by Salazar (2009). We believe that the petals not adnate to the gynostemium, triangular stigma, bifid rostellum and lack of hamulus clearly separate this species from all other representatives of Ponthieva.

Regarding the exclusion of Exallaria from Ponthieva, the genus is clearly defined on the morphological level. Its representatives usually grow as terrestrial plants in humid forested areas but also are found in disturbed zones of plantations or on road edges (Dueńas Gómez \& Fernández Alonso 2009). Plants have been found in lowland as well as in high mountains, up to $c a 3200 \mathrm{~m}$ a.s.l. The geographical range of the genus extends from the southern USA south to northern Argentina.

During studies on Neotropical spiranthoid orchids we came across a distinctive Ponthieva species. The specimen was found in Heinrich G. Reichenbach's collection stored in the 
Herbarium of the Natural History Museum in Vienna (W). The finding is described here as new.

Ponthieva jamesonii Kolan. \& Szlach., sp. nov.

Fig. 1

Species similar to Ponthieva rostrata Lindl., distinguished by its glabrous, obliquely ovate, rounded, undulate petals and relatively short obovate apical lobule of the lip.

HoLOTYPE: ECUADOR, Near Loja. Jameson s.n. (W).

Plants up to $40 \mathrm{~cm}$ tall, delicate. Leaves 4, basal, petiolate; petiole $2 \mathrm{~cm}$ long; blade up to $6.5 \mathrm{~cm}$ long and $2.2 \mathrm{~cm}$ wide, oblong-elliptic, acute. Scape erect, terminated in a raceme $6 \mathrm{~cm}$ long. Flowers small, sepals sparsely glandular. Floral bracts up to $11 \mathrm{~mm}$ long, sparsely glandular. Pedicellate ovary up to $12 \mathrm{~mm}$ long, glandular. Dorsal sepal up to $6 \mathrm{~mm}$ long and $3.5 \mathrm{~mm}$ wide, ovate-lanceolate, obtuse, 3-nerved. Petals clawed; claw free part $1 \mathrm{~mm}$ long; lamina $6 \mathrm{~mm}$ long and $3.8 \mathrm{~mm}$ wide, obliquely ovate, rounded at apex, nerves 3 , branching. Lateral sepals up to $8 \mathrm{~mm}$
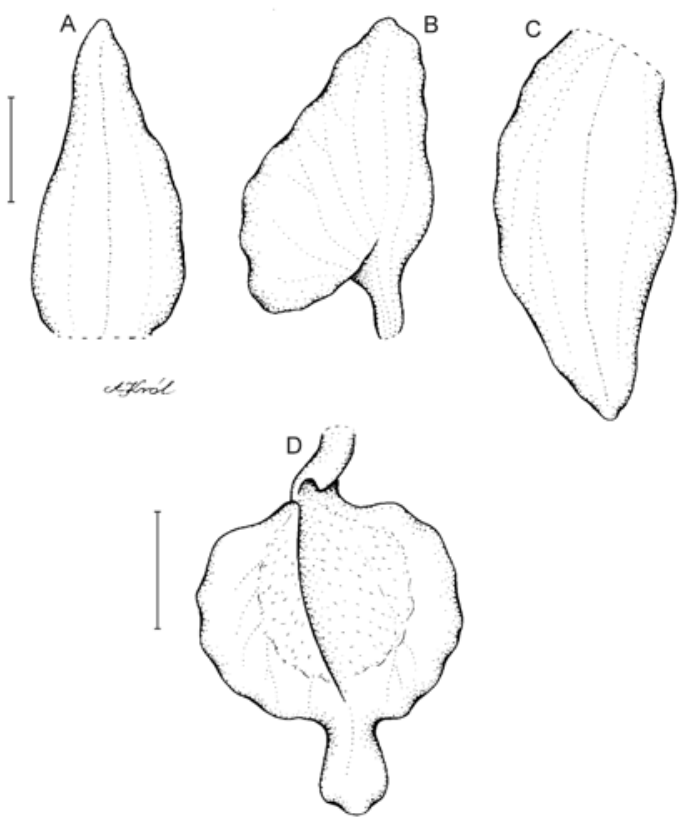

Fig. 1. Ponthieva jamesonii Kolan. \& Szlach. - dissected perianth. A - dorsal sepal, B - petal, C - lateral sepal, D - lip. Scale bars $=2 \mathrm{~mm}$. Drawn by A. Król from holotype.
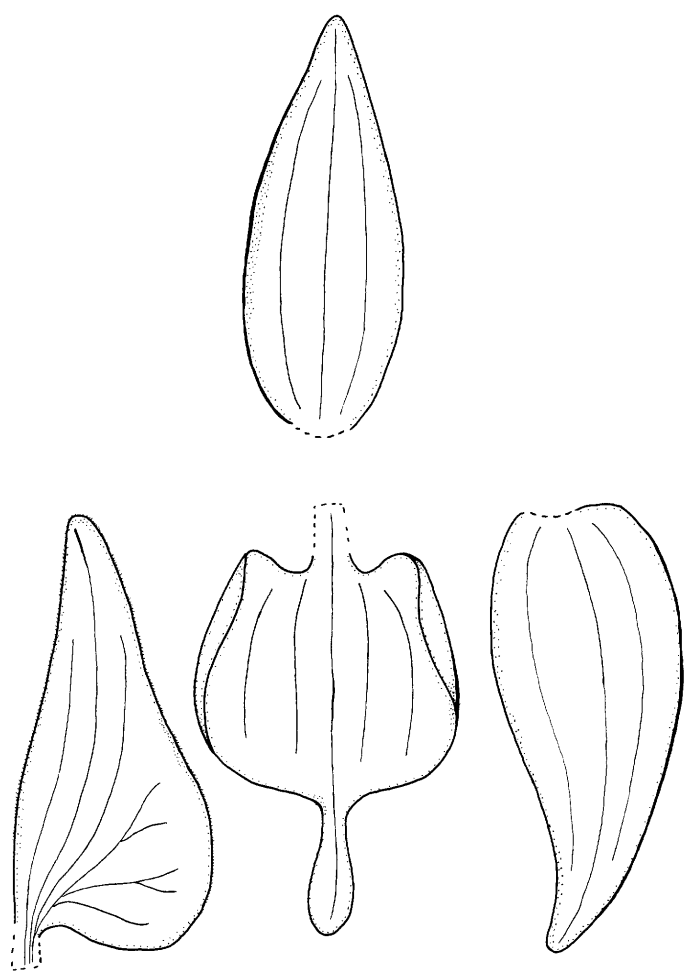

Fig. 2. Ponthieva rostrata Lindl. - dissected perianth. Redrawn from Schlechter (1930).

long and $3.3 \mathrm{~mm}$ wide, obliquely ovate, obtuse, 3-nerved. Lip distinctly short-unguiculate, claw ca $1.2 \mathrm{~mm}$ long, lamina up to $4 \mathrm{~mm}$ long and $4.6 \mathrm{~mm}$ wide when expanded, concave, subcordate at base, in front provided with a obovate, rounded lobe $1.3 \mathrm{~mm}$ long and $0.9 \mathrm{~mm}$ wide; disc papillose in major part.

Etymology. Dedicated to William Jameson (1796-1873), the collector of the original material.

Notes. This species resembles $P$. rostrata Lindl. (Fig. 2), known from Colombia, Ecuador and Peru (Garay 1978; Ortiz Valdivieso \& Uribe Vélez 2007), from which it is easily distinguished by its obliquely ovate, rounded, undulate petals (vs petals obliquely ovate-triangular to triangulardolabriform, acute) which are glabrous on margins (vs distinctly ciliolate) and by the rather short, obovate apical lobule of the lip (vs lobule elongate, linear). 
ACKNOWLEDGEMENTS. We are grateful to the Curator and staff of the Herbarium of the Natural History Museum in Vienna for their kind hospitality and assistance during visits, the anonymous reviewers for helpful suggestions on the manuscript, and Anna Król for preparing the illustration. The research described here was supported by the Polish Ministry of Science and Higher Education (grant no. 8124/B/PO1/2011/40) and a Synthesys grant (AT-TAF-2483).

\section{REFERENCES}

Brown R. 1813. Hortus Kewensis. 5. Richad Taylor and Co., London.

Dueńas Gómez H. del C. \& Fernández Alonso J. L. 2009. Sinopsis de la subfamilia Spiranthoideae (Orchidaceae) en Colombia, Parte II. Revista Acad. Colomb. Ci. Exact. 33: $157-181$.

Garay L. A. 1978. 225(1). Orchidaceae (Cypripedioideae, Orchidoideae, Neottioideae). In: G. W. HARLing \& B. B. Sparre (eds), Flora of Ecuador. 9. University of Göteborg \& Swedish Museum of Natural History, Göteborg \& Stockholm.
Garay L. A. \& Romero G. A. 1999. Schedulae Orchidium II. Harvard Pap. Bot. 4(2): 475-488.

KRÄNZLIN F. 1899. Orchidaceae Lehmannianae in Guatemala, Costarica, Columbia et Ecuador collectae, quas determinavit et descripsit. Bot. Jahrb. Syst. 26: 437-502.

Ortiz Valdivieso P. \& Uribe Vélez C. 2007. Galería de Orquídeas de Colombia (CD edition). Asociación Bogotana de Orquideología, Bogotá.

Salazar G., Cabrera L. I., Madrinan S. \& Chase M. W. 2009. Phylogenetic relationships of Cranichidinae and Prescottiinae (Cranichideae) inferred from plastid and nuclear DNA sequences. Ann. Bot. 104(3): 403-416.

SAlazar G. A. 2005. A new species of Ponthieva (Orchidaceae, Cranichidiinae) from Veracruz, Mexico. Brittonia 57(3): 252-254.

SCHLECHTER R. 1921. Die Orchideenfloren der südamerikanischen Kordillerenstaaten, III. Ecuador. Repert. Spec. Nov. Regni Veg. Beih. 8: 1-172.

SchlechteR, R. 1930. Blütenanalysen neuer Orchideen, I. Südamerikanische Orchideen. Repert. Spec. Nov. Regni Veg. 58: 1-60.

Szlachetko D. L. \& RutKowski P. 2000. Gynostemia Orchidalium. 1. Apostasiaceae, Cypripediaceae, Orchidaceae (Thelymitroideae to Vanilloideae). Acta. Bot. Fenn. 169: 1-415. 